
Not for reproduction, distribution or commercial use.

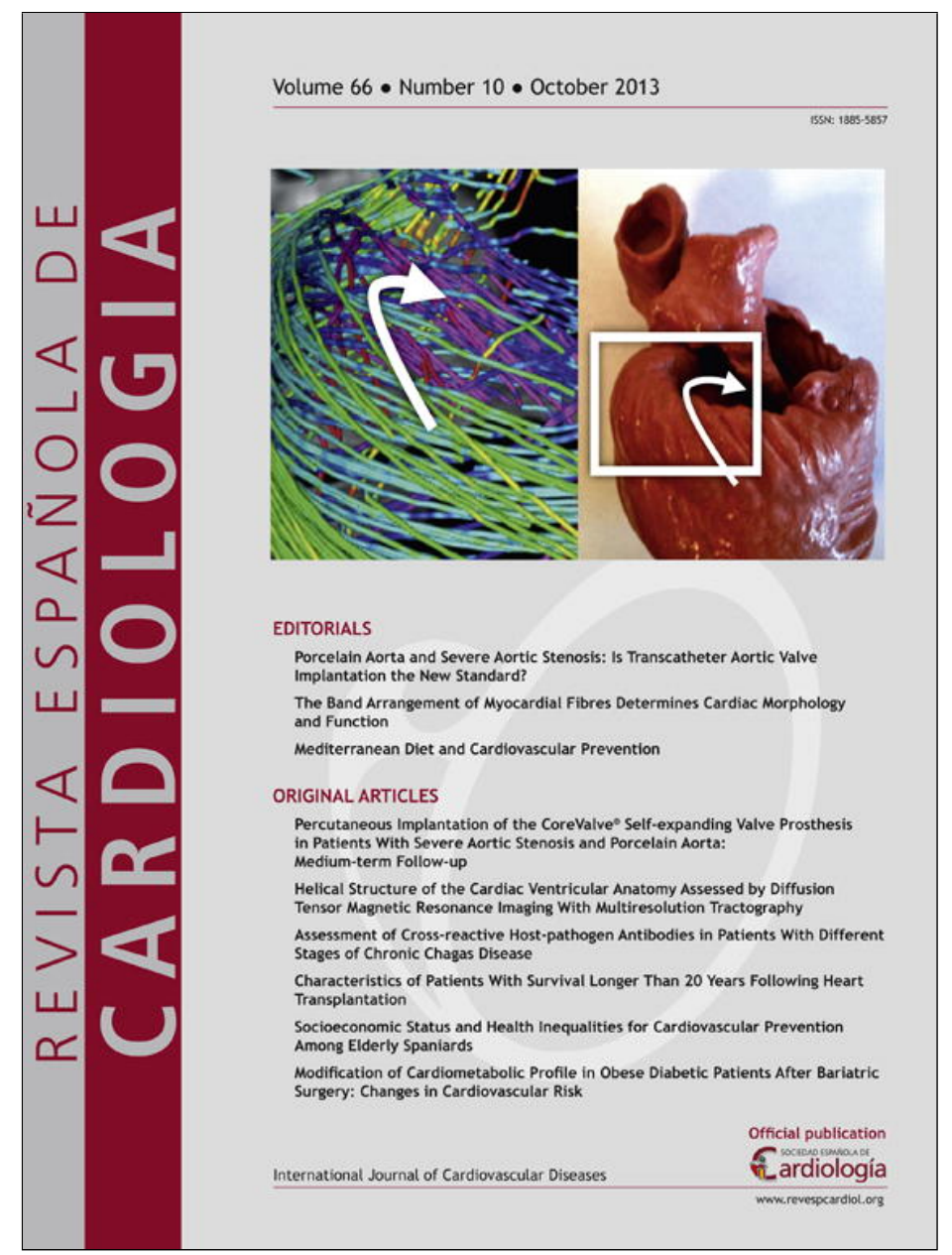

This article appeared in a journal published by Elsevier. The attached copy is furnished to the author for internal non-commercial research and education use, including for instruction at the authors institution and sharing with colleagues.

Other uses, including reproduction and distribution, or selling or licensing copies, or posting to personal, institutional or third party websites are prohibited.

In most cases authors are permitted to post their version of the article (e.g. in Word or Tex form) to their personal website or institutional repository. Authors requiring further information regarding Elsevier's archiving and manuscript policies are encouraged to visit: 


\title{
Assessment of Cross-reactive Host-pathogen Antibodies in Patients With Different Stages of Chronic Chagas Disease
}

\author{
Miguel H. Vicco, ${ }^{\mathrm{a}, \mathrm{b}, *}$ Franco Ferini, ${ }^{\mathrm{b}}$ Luz Rodeles, ${ }^{\mathrm{b}}$ Paula Cardona, ${ }^{\mathrm{a}}$ Iván Bontempi, ${ }^{\mathrm{a}}$ Susana Lioi, ${ }^{\mathrm{c}}$ \\ Juan Beloscar, ${ }^{\mathrm{d}}$ Takeshi Nara, ${ }^{\mathrm{e}}$ Iván Marcipar, ${ }^{\mathrm{a}}$ and Oscar A. Bottasso ${ }^{\mathrm{f}}$ \\ a Laboratorio de Tecnología Inmunológica, Facultad de Bioquímica y Ciencias Biológicas, Universidad Nacional del Litoral, Santa Fe, Argentina \\ ${ }^{\mathrm{b}}$ Servicio de Clínica Médica, Hospital J.B. Iturraspe, Santa Fe, Argentina \\ ' Cátedra de Química Analítica Clínica, Facultad de Ciencias Bioquímicas y Farmacéuticas, Universidad Nacional de Rosario, Santa Fe, Argentina

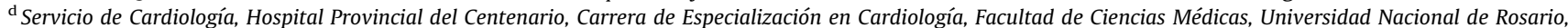 \\ Santa Fe, Argentina \\ e Departamento de Parasitología Celular y Molecular, Escuela de Medicina, Universidad de Juntendo, Tokyo, Japan \\ ${ }^{\mathrm{f}}$ Instituto de Inmunología, Facultad de Medicina, Universidad Nacional de Rosario, Santa Fe, Argentina
}

\section{Article history:}

Received 5 April 2013

Accepted 10 May 2013

Available online 22 August 2013

\section{Keywords:}

Chagas disease

Trypanosoma cruzi

Heart failure

Anti-B13 autoantibodies

\begin{abstract}
A B S T R A C T
Introduction and objectives: Trypanosoma cruzi infection has been shown to induce humoral autoimmune responses against host antigens tissues. Particularly, antibodies cross-reacting with myocardial antigens may play a role in the development of the severe forms of chronic Chagas disease. The aim of this study was to determine the association between clinical stage of the disease and the presence of autoantibodies in patients with chronic Chagasic disease.

Methods: We performed a cross-sectional study in T. cruzi-seropositive patients divided into 3 groups according to the classic classification of chronic Chagas heart of Storino et al. All participants underwent complete clinical examination and their sera were used to measure autoantibody levels.

Results: All patients had detectable levels of anti-p2 $\beta$ and anti-B13 autoantibodies but none had antiNa-K-ATPase antibodies. No association was observed between electrocardiographic conduction disturbances and autoantibody levels. Patients with chronic Chagas disease stage III had the highest levels of anti-B13 antibodies and a high risk of mortality score, showing a clear association between disease stage and this score.

Conclusions: Anti-B13 antibodies were significantly higher in chronic Chagas disease stage III patients, suggesting that these antibodies may be involved in disease progression and that they might be a useful marker of poor prognosis in terms of heart compromise. Our results also reveal an important correlation between the level of anti-B13 autoantibodies and symptomatic heart failure and/or dilated cardiomyopathy.
\end{abstract}

(C) 2013 Sociedad Española de Cardiología. Published by Elsevier España, S.L. All rights reserved.

Valoración de anticuerpos con reactividad cruzada patógeno-huésped en pacientes con diferentes estadios de cardiopatía chagásica crónica

R E S U M E N

Introducción y objetivos: La infección por Trypanosoma cruzi induce una respuesta autoinmunitaria humoral contra diferentes antígenos del huésped. En especial, los anticuerpos que presentan reactividad cruzada con antígenos del miocardio tienen un papel importante en el desarrollo de las formas graves de la cardiopatía chagásica crónica. En este trabajo se analiza la asociación del estadio clínico de la enfermedad con la presencia de autoanticuerpos en pacientes con cardiopatía chagásica crónica.

Métodos: Estudio transversal con pacientes con serología positiva para enfermedad de Chagas, categorizados en tres grupos según la clasificación de cardiopatía chagásica de Storino et al. Se realizó a todas las personas incluidas un examen clínico completo y se usaron las muestras de suero para cuantificar los autoanticuerpos.

Resultados: Todos los pacientes presentaron cantidades detectables de anti-p2 $\beta$ y anti B13; el anti$\mathrm{Na}$-K-ATPasa fue negativo en todos los casos. No se halló asociación significativa entre las alteraciones electrocardiográficas y los valores de autoanticuerpos. Los pacientes con cardiopatía chagásica en estadio III presentaron mayor concentración de anti-B13 y riesgo de mortalidad alto, lo que muestra una clara asociación entre el estadio de la enfermedad y la puntuación de mortalidad.

Conclusiones: La concentración del autoanticuerpo anti-B13 fue significativamente mayor en los pacientes con cardiopatía chagásica en estadio III, lo que indica que este anticuerpo puede estar involucrado en la progresión de la enfermedad y podría usarse como marcador de mal pronóstico

\footnotetext{
* Corresponding author: Laboratorio de Tecnología Inmunológica, Facultad de Bioquímica y Ciencias Bioquímicas, Universidad Nacional del Litoral, Ciudad Universitaria, CC242, 3000 Santa Fe, Argentina.

E-mail address: mvicco@santafe-conicet.gov.ar (M.H. Vicco).
} 
respecto a la afección cardiaca. Los resultados revelan también una importante correlación entre el anti-B13 y la insuficiencia cardiaca sintomática y/o la cardiomiopatía dilatada.

(๑) 2013 Sociedad Española de Cardiología. Publicado por Elsevier España, S.L. Todos los derechos reservados.

\section{Abbreviations}

\section{CCD: chronic Chagas disease}

IODN: index of the optical density of autoantibodies in relation to the negative control
The present study was designed to evaluate the presence of anti-p2 $\beta$, anti-B13 immunoglobulins, and the still unexplored anti- $\mathrm{Na}^{+} / \mathrm{K}^{+}$pump ATPase antibody in patients with CCD. The possible association between serum levels of these antibodies and the degree of cardiac compromise was assessed and the risk of mortality score was also determined.

\section{METHODS}

\section{INTRODUCTION}

Chagas disease, a parasitic infection caused by the protozoan Trypanosoma cruzi, affects at least 8-10 million people throughout South and Central America. Sporadic cases have also been reported in the United States and Europe. The major complications of this disease are mega syndromes involving the gastrointestinal tract or/and the heart. Chronic Chagas disease (CCD) is the most common manifestation, affecting about $30 \%$ of individuals infected with $T$. cruzi. Severe heart disorders, such as rhythm or conduction abnormalities, as well as a specific dilated cardiomyopathy or thromboembolic episodes, may cause approximately 50000 deaths annually. ${ }^{1,2}$

The mechanisms underlying the pathogenesis of Chagas disease are complex and multifactorial, ${ }^{3,4}$ with immune responses to parasite antigens, ${ }^{5,6}$ autoimmune processes, ${ }^{7-9}$ and the inflammatory response accompanying these reactions being likely to be involved. ${ }^{10-15} \mathrm{~A}$ humoral autoimmune response due to the molecular mimicry displayed by some parasite proteins is one of the mechanisms involved in the pathogenesis of Chagas disease. Among the several autoantibodies that have been described, anti-p2 $\beta$ and anti-B13 have been shown to play a pathogenetic role in the development of heart tissue lesions, both in humans and in animal models. ${ }^{16}$ Anti-p2 $\beta$ antibodies cross-reacting against the $\beta 1$ adrenergic receptor have been involved in murine models of cardiac alterations, such as electrocardiographic abnormalities and myocyte apoptosis. ${ }^{17-23}$ Cross-reactivity is attributed to the antigenic acidic epitope present on the C-terminal end of the $\mathrm{p} 2 \beta$, named R13 (EEEDDDMGFGLFD), which shows a similarity to the AESDE acidic motif on the second extracellular loop of the $\beta 1$ adrenergic receptor. ${ }^{24}$ An assessment of anti-p2 $\beta$ antibodies in chagasic patients in different stages yielded no conclusive results as to their involvement in $\mathrm{CCD} .^{25,26}$ B13 antigen was shown to promote an autoantibody cellular response to cardiac myosin because of the sequence homology to B13 protein epitope (AAAGDK) of human cardiac myosin heavy chain hexapeptide (AAALDK). ${ }^{16,27,28}$ A study in patients with CCD reported a high prevalence of anti-B13 antibodies in patients with dilated cardiomyopathy, ${ }^{25}$ but the correlation of their levels with the degree of CCD involvement was not explored.

Recently, antibodies against $\mathrm{Na}+/ \mathrm{K}+$ pump ATPase were associated with dilated idiopathic cardiomyopathy and electrocardiographic conduction disturbances. ${ }^{29,30}$ Interestingly, the expression of a $\mathrm{Na}^{+} / \mathrm{K}^{+}$pump ATPase by $T$. cruzi has been described as a mechanism of adaptation from the extracellular to the intracellular cycle. ${ }^{31} \mathrm{As} \mathrm{Na}^{+} / \mathrm{K}^{+}$pump ATPase has a human-parasite highly conserved amino acid sequence, autoantibodies against this protein might play a role in CCD pathogenesis due to a molecular mimicry mechanism triggered by this protein.

\section{Study Population and Subject Evaluation}

We performed a cross-sectional study in 80 patients with a positive serological test for T. cruzi. Diagnosis of Chagas disease was established according to the recommendation of the World Health Organization with 2 different tests (ELISA and indirect hemagglutination or indirect immunofluorescence) yielding positive results. ${ }^{32}$ Patients were divided into 3 groups according to the CCD classification of Storino et al. ${ }^{33}$ All individuals were recruited at the clinical service of the Iturraspe Hospital (Santa Fe, Argentina), and underwent a complete clinical examination, including the following tests: full blood count, glucose, potassium, creatinine, blood urea nitrogen, electrocardiogram, chest and abdominal X-ray, and echo Doppler cardiography. The echocardiograms were performed according to Acquatella. ${ }^{34}$ Exclusion criteria included the presence of 2 or more risk factors for coronary artery disease or established disease, a history of other cardiac diseases, renal disturbances, thyroid disease or any other systemic complaints, as well as treatment with anti-T. cruzi compounds or immunosuppressive drugs. The study received ethical approval from the Ethics Review Board of the Universidad Nacional del Litoral. Informed consent was obtained from all patients.

According to the above-mentioned classification, we included: a) 30 individuals with CCD stage I (ie, with normal radiological studies, electrocardiogram and echocardiogram); b) 25 patients with CCD stage II (ie, with electrocardiographic changes such as left anterior divisional block, right bundle branch block, total atrioventricular block, left or right bundle branch block, complex ventricular arrhythmias, and block of the anterosuperior division of the left branch), and c) 25 patients with CCD stage III (ie, with clinical heart failure and/or dilated cardiomyopathy by echocardiogram. Clinical heart failure was defined according the $2012 \mathrm{~g}$ Guidelines for the diagnosis and treatment of acute and chronic heart failure of the European Society of Cardiology. ${ }^{35}$ All patients in this group had a diagnosis of heart failure and none was receiving specific treatment for this condition at the time of inclusion.

A control group of 10 patients was included. These patients had dilated cardiomyopathy and heart failure due to hypertension/ coronary artery disease.

\section{Protein Expression and Purification}

Eschericia coli BL21(DE3) cells bearing the plasmidic constructions pET-32a/p2 $\beta$, pET-32a/B13 were grown overnight in LB medium, supplemented with $0.1 \mathrm{mg} \times \mathrm{mL} / 1$ ampicillin at $37{ }^{\circ} \mathrm{C}$, with agitation. Protein expression was induced in $1 \mathrm{mM}$ isopropyl$\beta$-D-thiogalactopyranoside and was purified with a Ni-nitrilotriacetic acid column (GE), as described elsewhere. ${ }^{36}$ E. coli BL21(DE3) 
cells bearing the plasmidic constructions pET28a/TcENA (as Na ${ }^{+} / \mathrm{K}^{+}$ pump ATPase) were induced by incubating the cells in $1 \mathrm{mM}$ isopropyl- $\beta$-D-thiogalactopyranoside. The bacterial cells were lysed by sonication and were precipitated by centrifugation at $10000 \times \mathrm{g}$ for $10 \mathrm{~min}$ at $4{ }^{\circ} \mathrm{C}$. The resulting precipitate was solubilized with 8 mol UREA, incubated with TALON Metal Affinity Resin (BD Biosciences; San Jose, California, United States) and dialyzed, as described by lizumi et al. ${ }^{31}$

\section{Antibody Measurement}

Serum samples were obtained by conventional venipuncture, and antibodies were measured by immunoassay (ELISA). Microtiter plates were coated with $0.5 \mu \mathrm{g}$ of the specific antigen in $0.05 \mathrm{M}$ carbonate-bicarbonate buffer, $\mathrm{pH} 9.6$ and were incubated overnight at $4{ }^{\circ} \mathrm{C}$. Plates were blocked with $5 \%$ bovine serum albumin and were incubated with a 1:100 dilution of human serum in duplicate. Plates were read at $450 \mathrm{~nm}$ in an ELISA reader (BioRad). All serum samples were evaluated in duplicate, with the result of the test being the mean optical density value of these simultaneous assessments. In each plate, 6 negative controls (healthy individuals seronegative for $T$. cruzi), were simultaneously assayed. ${ }^{36}$ ELISAnegative standard cutoff values were calculated as the mean optical density of the negative serum samples plus 2 standard deviations. Antibody levels were expressed as an index that represents the ratio between the optical density of the sample and the optical density of the negative standard cutoff. This index is referred to as IODN (index of the optical density of autoantibodies in relation to the negative control). An IODN $\leq 1$ was considered negative. ${ }^{36-38}$

\section{Mortality Score}

The risk score for predicting death in Chagas heart disease $\mathrm{e}^{39,40}$ was applied in all patients. Patients were included into low- and high-risk groups because there were no intermediate-risk patients.

\section{Statistical Analysis}

Data were analyzed with MedCalc version 12.2.1. Normal distributions of the continuous variables were tested by the Kolmogorov-Smirnov method. The data are expressed as means (standard deviation) or median and interquartile range. Groups were compared in relation to age, antibody levels, and CCD stages. The Chi-square test or Fisher's exact test was used for categorical variables and one-way analysis of variance (Student-NewmanKeuls test for all pairwise comparisons) was used to compare the means of IODN values and age among the groups defined by CCD stage. Multiple binary logistic regression models were used to assess the impact of variables that were associated $(P<.05)$ with heart failure in Chagas disease. Confounders and independent risk factors were included in the final logistic regression model. A receiver operating characteristic curve was constructed to explore whether the IODN of antibodies was useful to discriminate among patients with different $\mathrm{CCD}$ stages. A $P$ value of $<.05$ was considered significant.

\section{RESULTS}

\section{General Population}

The mean age of sampled individuals was 55 (12.4) years; 56\% were women. There were no between-group differences in age or sex distribution. Patients in CCD stage III were unaware of being infected with $T$. cruzi until they were admitted to the hospital because of heart failure. Only 12 patients with CCD stage I and II knew they had Chagas disease. The remaining CCD individuals were diagnosed on the basis of a screening test because of positive epidemiology for Chagas disease.

Twelve patients with CCD stage II and 6 patients with CCD stage III had hypertension and were receiving enalapril. All patients in the control group were also hypertensive and were being treated with angiotensin-converting-enzyme inhibitors plus $\beta$-blockers. Systolic blood pressure was significantly lower in stage I individuals than in the remaining groups (Kruskall Wallis test, $P=.0042$ ).

The characteristics of the patients in each group and the distribution of the antibodies are summarized in Table 1 .

\section{Electrocardiographic Disturbances}

The most frequent electrocardiographic changes in CCD stage II and III were left anterior divisional block with right bundle branch block $(n=12)$, right bundle branch block $(n=7)$ and atrial fibrillation associated with right bundle branch block $(n=7)$. Sinus bradycardia was present in 4 patients with CCD stage II with sinus bradycardia, whereas 2 individuals with CCD stage III had third degree atrioventricular block requiring pacemaker implantation. Changes in the control group of patients with dilated cardiomyopathy were as follows: atrial fibrillation $(n=4)$, left ventricular hypertrophy $(n=3)$, atrial fibrillation and right bundle branch block ( $\mathrm{n}=2$ ), and left anterior divisional block and right bundle branch block $(n=1)$. There was no association between electrocardiographic conduction disturbances and hypertension or IODN values for anti-p2 $\beta$ and anti-B13 antibodies. There were no statistically significant differences in the occurrence of pathological electrocardiogram tracings between patients with CCD (stage II and III) and the control group.

\section{Echocardiographic Findings}

Four individuals in the CCD II group had apical septal hypokinesis without diastolic or systolic disturbance and 2 patients had concentric ventricular hypertrophy. Among the 25 individuals with CCD III, 53\% had globally dilated cardiomyopathy with reduced ejection fraction, 30\% had left atrial enlargement and abnormal left ventricular relaxation with diastolic heart failure, and $17 \%$ had concentric ventricular hypertrophy with diastolic disturbance. In the control group, 7 patients had hypokinesis of the left ventricular walls associated with enlarged left cavities and reduced ejection fraction, 2 patients had globally dilated cardiomyopathy, and the remaining patient had apical septal hypokinesis associated with abnormal left ventricular relaxation and diastolic heart failure.

As expected, hypertension was associated with concentric ventricular hypertrophy $(P=.04)$.

\section{Antibodies}

All patients with Chagas disease had detectable levels of antip2 3 (2007 to 11207) and anti-B13 (1950 to 13525) autoantibodies, whereas none of them exhibited anti-Na-K-ATPase antibodies. All patients in the control group had negative results. Antibody levels did not correlate with age, sex distribution, or additional variables such as hypertension or enalapril treatment.

Comparison of anti-p2 $\beta$ antibodies revealed no intergroup differences in the CCD group, whereas patients with CCD stage III had the highest values of IODN for anti-B13 antibodies 
Table 1

Characteristics of Chronic Chagas Disease Patients by Group

\begin{tabular}{|c|c|c|c|c|c|}
\hline & \multicolumn{4}{|c|}{ Chronic Chagas heart disease } & \multirow[t]{2}{*}{$P$} \\
\hline & $I(n=30)$ & II $(n=25)$ & III $(n=25)$ & Control group $(\mathrm{n}=10)$ & \\
\hline Age & $49.7(12)$ & $53.5(11)$ & $58.4(8)$ & $61.1(5)$ & $.012^{\mathrm{a}}$ \\
\hline \multicolumn{6}{|l|}{ Gender, \% } \\
\hline Male & 30 & 48 & 48 & 60 & NS \\
\hline Female & 70 & 52 & 52 & 40 & \\
\hline Systolic blood pressure, $\mathrm{mmHg}$ & $120(11)$ & $130(10)$ & $130(10)$ & $130(10)$ & $.0042^{\mathrm{b}}$ \\
\hline Diastolic blood pressure, $\mathrm{mmHg}$ & $80(10)$ & $80(10)$ & $90(10)$ & $90(10)$ & .3 \\
\hline \multicolumn{6}{|l|}{ Risk of death score, \% } \\
\hline High risk & - & - & 100 & Non aplicable & $<.001^{\mathrm{c}}$ \\
\hline Low risk & 100 & 100 & - & & \\
\hline Heart failure, \% & 0 & 0 & 100 & 100 & $<.001^{\mathrm{d}}$ \\
\hline Left ventricular ejection fraction, \% & $51.2(9.83)$ & $48.35(10.7)$ & $38.1(8.65)$ & $40.2(6.83)$ & $.03^{\mathrm{e}}$ \\
\hline \multicolumn{6}{|l|}{ Antibodies } \\
\hline IODN-p2 $\beta$ & $1.833(1.03)$ & $1.806(1.145)$ & $2.178(1.310)$ & $0.719(0.243)$ & $.001^{\mathrm{f}}$ \\
\hline IODN-B13 & $4.797(2.333)$ & $5.634(2.056)$ & $9.388(2.505)$ & $0.687(0.136)$ & $<.001^{\mathrm{g}}$ \\
\hline
\end{tabular}

CCD, chronic Chagas disease; IODN, index of the optical density of autoantibodies in relation to the negative control; NS, not significant.

Quantitative variables are expressed as means (standard deviation) and qualitative variables as proportions and percentages.

a CCD III and control group are different from CCD I and CCD II.

b CCD I is different from CCD II, CCD III and CG.

c CCD III is different from CCD I and CCD II.

d CCD III is different from CCD I and CCD II.

e CCD III and control group are different from CCD I and CCD II.

${ }^{f}$ Control croup is different from other groups.

g CCD III is different from other groups.

(F ratio=37.32; $P<.001$ ) (Fig. 1). This group showed a clear association with heart failure and a high risk of mortality score (Fisher's exact test $P<.001$ ).

There were no statistically significant differences between the degree of cardiomyopathy by echocardiogram and the IODN of autoantibodies. When hypertensive patients were excluded, we observed that levels of IODN of anti-B13 antibodies increased with progression of pathological echocardiographic signs (Fig. 2). In addition, patients with dilated cardiomyopathy and reduced ejection fraction had an increased level of IODN of anti-B13

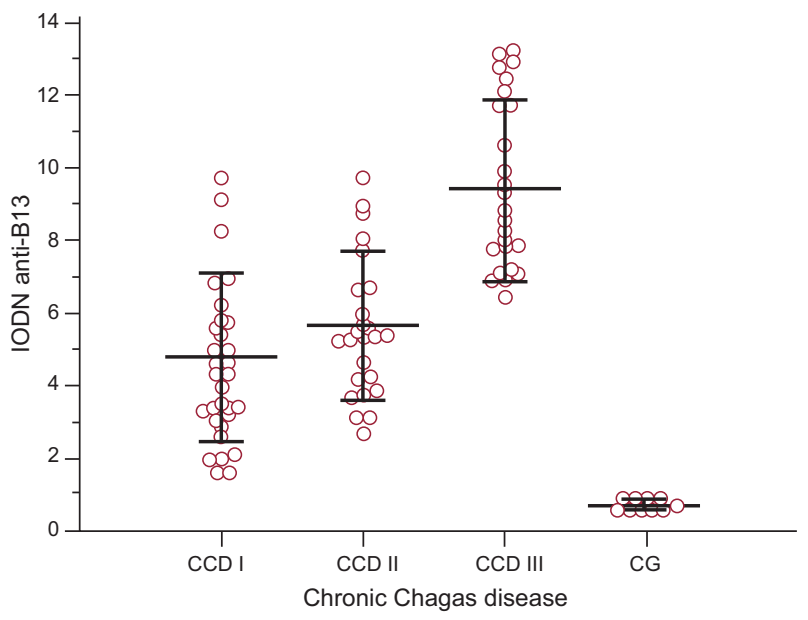

Figure 1. Levels of index of the optical density of autoantibodies in relation to the negative control of anti-B13 according to the degree of chronic Chagas disease and in the control group. Lines represent the means (standard deviation). Index of the optical density of autoantibodies in relation to the negative control antiB13 values in stage III individuals were significantly different from those in the remaining groups. Analysis of variance F-ratio=24.58 $(P<.001)$ (StudentNewman-Keuls test for all pairwise comparisons, $P<.05)$. CCD, chronic Chagas disease; CG, control group; IODN, index of the optical density of autoantibodies in relation to the negative control. compared with those without this alteration $(P<.001)$ in the populations serologically positive for Chagas disease. Patients with a high mortality score had higher levels of IODN anti-B13 compared with low-risk individuals $(P<.001)$.

A multiple binary logistic regression was conducted to predict clinical heart failure using the categorical variables of hypertension, gender, smoking, and alcohol consumption, and the continuous variables of age, level of IODN anti-p2 $\beta$ and IODN

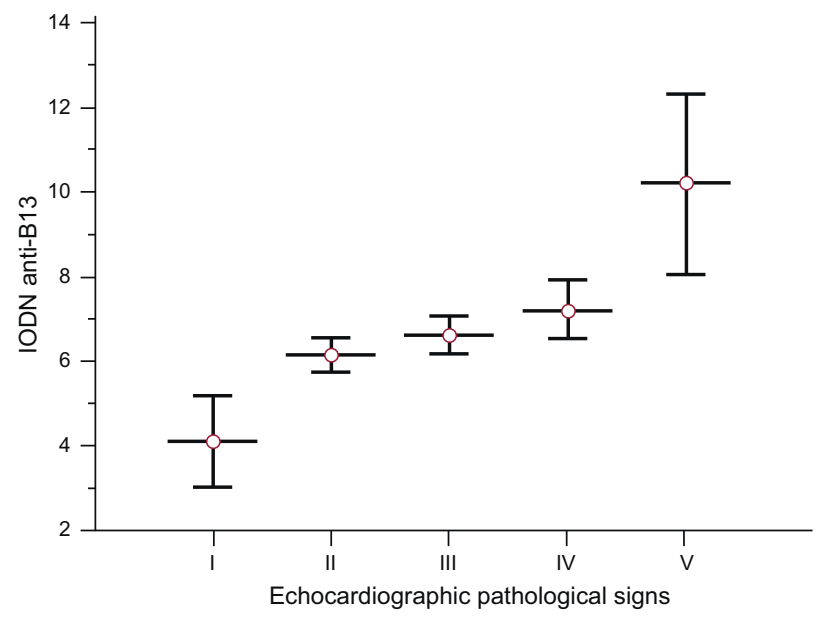

Figure 2. Levels of index of the optical density of autoantibodies in relation to the negative control of anti-B13 according to pathological echocardiographic signs. I: normal echocardiogram, II: apical-septal hypokinesis, III: concentric ventricular hypertrophy, IV: left atrial enlargement and abnormal left ventricular relaxation with diastolic heart failure, V: globally dilated cardiomyopathy with reduced ejection fraction; IODN, index of the optical density of autoantibodies in relation to the negative control. Lines represent the median (standard deviation). Patients with dilated cardiomyopathy and reduced ejection fraction had a statistically significantly increased level of index of the optical density of autoantibodies in relation to the negative control compared with those lacking this alteration. Analysis of variance $F$ ratio $=61.91$ $(P<.001)$ (Student-Newman-Keuls test for all pairwise comparisons, $P<.05)$. 
Table 2

Summary of Variables and Odd Ratios

\begin{tabular}{lll} 
Variables & OR $(95 \% \mathrm{CI})$ & $P$ \\
\hline Age & $1.04(0.97-1.12)$ & .2 \\
\hline Gender & & .5 \\
\hline Male & $0.53(0.08-3.35)$ & .5 \\
\hline Female & $1.88(0.29-11.93)$ & .9 \\
\hline Hypertension & $1.10(0.19-6.64)$ & .6 \\
\hline Smoking & $1.65(0.16-16.26)$ & .5 \\
\hline Alcohol consumption & $0.52(0.06-4.00)$ & .1 \\
\hline Antibodies & & .0002 \\
\hline IODN-p2 $\beta$ & $0.80(0.57-1.10)$ & \\
\hline IODN-B13 & $2.00(1.50-3.43)$ &
\end{tabular}

95\%CI, 95\% confidence interval; IODN, index of the optical density of autoantibodies in relation to the negative control; OR: odds ratio.

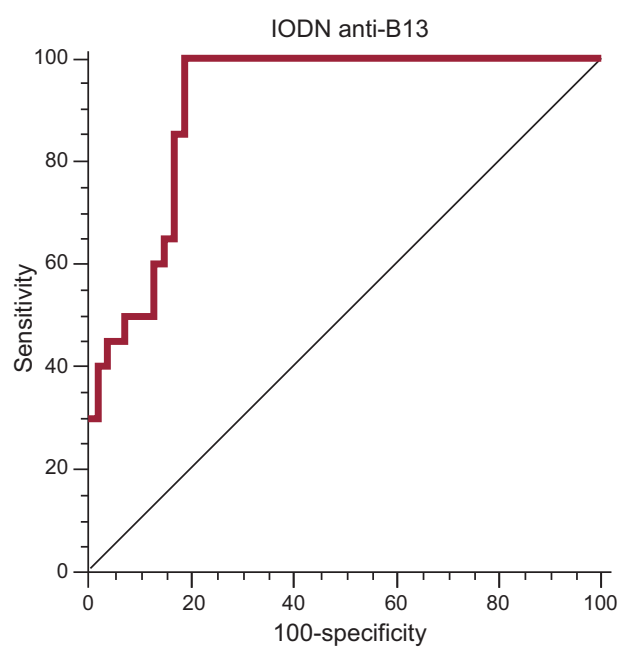

Figure 3. Receiver operating characteristic curve of index of the optical density of autoantibodies in relation to the negative control anti-B13 as a serological marker of chronic Chagas disease stage III. Area under the curve of $0.87 \%(P<.001)$ for index of the optical density of autoantibodies in relation to the negative control of anti-B13 of 6.655 . Sensitivity of $99 \%$ (95\% confidence interval: $78.2-$ 99.0) and specificity of $74.58 \%$ (95\% confidence interval: 61.6-85.0). IODN, index of the optical density of autoantibodies in relation to the negative control.

anti-B13. The Wald criterion demonstrated that only IODN antiB13 significantly contributed to prediction (odds ratio=2; 95\% confidence interval $[95 \% \mathrm{CI}], 1.501-3.430 ; P=.0002)$, which was linearly-related (Table 2). We also calculated the receiver operating characteristic curve of IODN anti-B13 yielding an area under the curve of $0.87 \%(P<.001)$ for an IODN anti-B13 of 6.655 , with a sensitivity of $99 \%$ (95\% CI: 78.2-99.0) and a specificity of 74.58\% (95\%CI: 61.6-85.0) (Fig. 3).

\section{DISCUSSION}

The autoimmune response against myocardial antigens may play a role in the development of severe forms of CCD. ${ }^{16}$ In the present study, we assessed the influence of molecular mimicry in promoting autoimmune antibody response in patients with cardiopathy.

As an additional aim related to the autoantibody analysis, we evaluated whether $\mathrm{Na}^{+} / \mathrm{K}^{+}$pump ATPase of $T$. cruzi induced an autoimmune reaction. These autoantibodies have not previously been investigated in patients with Chagas disease, but their presence has been detected in other myocardiopathy patients. We hypothesized that these autoantibodies might be induced by parasitic infection based on a previously reported phylogenetic analysis indicating that type IIC $\mathrm{Na}^{+} / \mathrm{K}^{+}$and $\mathrm{H}^{+} / \mathrm{K}^{+}$ATPases of organisms from different kingdoms have conserved sequences excluding the highly variable N-terminal and C-terminal regions. ${ }^{41}$ We were unable to find antibodies against the protein of the parasite cationic pump in any of the patients with Chagas disease. Although the parasite must express this pump to survive inside of the host cell, ${ }^{31}$ it is apparent that the immunogenicity of this antigen and/or the amount of the antigen and/or the routes of antigenic presentation do not trigger the proliferation of $B$ cell clones against this antigen in T. cruzi human infection. As such, this antigen may not be involved in the mimicry-driven production of autoantibodies.

Among autoantibodies promoted by the parasite antigens, anti$\mathrm{p} 2 \beta$ and anti-B13 are the best characterized. These antibodies have been found in the sera of experimentally infected animals and patients with Chagas disease. ${ }^{16,27,42}$ Some studies suggest that these antibodies may induce functional and structural alterations of the cardiac tissue during experimental Chagas disease. $^{9,17-24,43,44}$ In addition, our results showed that individuals with CCD had antibodies against peptide sequences of both adrenergic receptor and cardiac myosin. Anti-p2 $\beta$ was present in the entire study population, showing no between-group differences and being unrelated to clinical manifestations; these results are consistent with those of other studies. Talvani et al. ${ }^{26}$ found no correlation between anti-p2 $\beta$ and different CCD stages, but these authors used a small sample size. Brenière et al. ${ }^{25}$ also found no association between anti-p2 $\beta$ levels and electrocardiogram changes, although patients with heart failure were not included in the study. In the present study, the degree of pathological echocardiographic signs, electrocardiographic conduction disturbances and heart failure showed no relationship with levels of antip2 $\beta$ antibodies. Concerning anti-B13, Cunha-Neto et al. ${ }^{27}$ reported that cardiac myosin-B13 cross-reactive antibodies were present in all Chagas patients with heart failure, but only in $14 \%$ of asymptomatic $T$. cruzi seropositive individuals. All the patients serologically-positive for Chagas disease included in our study had anti-B13 antibodies, as reported previously, ${ }^{45}$ and their levels were significantly higher in CCD stage III patients. In addition, the comparison of the level of anti-B13 in relation to the pathological echocardiographic signs showed that these autoantibodies increase as structural cardiac involvement progresses.

\section{CONCLUSION}

Our results reflect an important correlation between the level of anti-B13 autoantibodies and symptomatic heart failure and pathological signs on echocardiography, suggesting that these antibodies may be involved in disease progression. However, longitudinal studies are needed to ascertain whether anti-B13 autoantibodies may have a predictive value in CCD.

\section{ACKNOWLEDGMENTS}

This study was funded by CONICET (National Scientific and Technical Research Council) and the Universidad Nacional del Litoral (Santa Fe, Argentina). MHV and IB are research fellows of CONICET. ISM and OB are research career members of CONICET.

\section{CONFLICTS OF INTERESET}

None declared. 


\section{REFERENCES}

1. Control of Chagas disease: second report of a WHO expert, committee. World Health Organ Tech Rep Ser. 2002;905:1-109.

2. Organización Panamericana de la Salud. Estimación cuantitativa de la enfermedad de Chagas en las Américas. Montevideo, Uruguay: OMS; 2006.

3. Marin-Neto JA, Rassi Jr A. Actualización sobre la cardiopatía de la enfermedad de Chagas en el primer centenario de su descubrimiento. Rev Esp Cardiol. 2009;62:1211-6

4. Da Silva CA, Fattori A, Sousa AL, Mazon SB, Monte Alegre S, Almeida EA, et al Determinación de la concentración plasmática de proteína $C$ reactiva en pacientes con diferentes formas clínicas de la enfermedad de Chagas. Rev Esp Cardiol. 2010;63:1096-9.

5. Almeida HO, Teixeira VPA, Dos Reis MA, Franciscon JU, Martins E. Modificações nucleares em células parasitadas pelo Trypanosoma cruzi em chagásicos crônicos. Rev Soc Bras Med Trop. 1987;20:147-51.

6. Almeida HO, Brandão MC, Dos Reis MA, Gobbi H, Teixeira VPA. Denervation and heart disease in patients with chronic Chagas' disease. Arq Bras Cardiol. $1987 ; 48: 43-7$

7. Gironès N, Fresno M. Etiology of Chagas disease myocarditis: autoimmunity parasite persistence, or both? Trends Parasitol. 2003;19:19-22.

8. Kalil J, Cunha-Neto E. Autoimmunity in chagas disease cardiomyopathy: Fulfilling the criteria at last? Parasitol Today. 1996;12:396-9.

9. Leon JS, Engman DM. Autoimmunity in Chagas heart disease. Int J Parasitol. 2001;31:555-61

10. Brener Z, Gazzinelli RT. Immunological control of Trypanosoma cruzi infection and pathogenesis of Chagas' disease. Int Arch Allergy Immunol. 1997;114: 103-10.

11. Higuchi ML, De Morais CF, Pereira Barreto AC, Lopes EA, Stolf N, Bellotti G, et al. The role of active myocarditis in the development of heart failure in chronic Chagas' disease: a study based on endomyocardial biopsies. Clin Cardiol. 1987:10:665-70

12. Pontes-de-Carvalho L, Santana CC, Soares MB, Oliveira GG, Cunha-Neto E, Ribeiro-dos-Santos R. Experimental chronic Chagas' disease myocarditis is an autoimmune disease preventable by induction of immunological tolerance to myocardial antigens. J Autoimmun. 2002;18:131-8.

13. Soares MB, Pontes-de-Carvalho L, Ribeiro-dos-Santos R. The pathogenesis of Chagas' disease: when autoimmune and parasite-specific immune responses meet. An Acad Bras Cienc. 2001;73:547-59.

14. Coura JR, Viñas PA. Chagas disease: a new worldwide challenge. Nature 2010;465:S6-7

15. Coura JR, Borges-Pereira J. Chagas disease: 100 years after its discovery. A systemic review. Acta Trop. 2010;115:5-13.

16. Cunha-Neto E, Teixeira PC, Nogueira LG, Kalil J. Autoimmunity Adv Parasitol. 2011;76:129-52.

17. Cremaschi G, Fernández M, Gorelik G, Goin J, Fossati C, Zwirner N, et al. Modulatory effects on myocardial physiology induced by an anti- monoclonal antibody involve recognition of major antigenic epitopes from ß-adrenergic and M-muscarinic cholinergic receptors without requiring receptor crosslinking. J Neuroimmunol. 2004;153:99-107.

18. Joensen L, Borda E, Kohout T, Perry S, García G, Sterin-Borda L. Trypanosoma cruzi antigen that interacts with the $ß 1$-adrenergic receptor and modifies myocardial contractile activity. Mol Biochem Parasitol. 2003;127:169-77.

19. Ferrari I, Levin MJ, Wallukat G, Elies R, Lebesgue D, Chiale P, et al. Molecular mimicry between the immunodominant ribosomal protein P0 of Trypanosoma cruzi and a functional epitope on the human beta 1-adrenergic receptor. J Exp Med. 1995;182:59-65.

20. Labovsky V, Smulski CR, Gómez K, Levy G, Levin MJ. Anti-beta1-adrenergic receptor autoantibodies in patients with chronic Chagas heart disease. Clin Exp Immunol. 2007;148:440-9.

21. Grippo V, Niborski LL, Gomez KA, Levin MJ. Human recombinant antibodies against Trypanosoma cruzi ribosomal P2 ß protein. Parasitology. 2011;138: 736-47.

22. Levy GV, Tasso LM, Longhi SA, Rivello HG, Kytö V, Saukko P, et al. Antibodies against the Trypanosoma cruzi ribosomal P proteins induce apoptosis in HL-1 cardiac cells. Int J Parasitol. 2011;41:635-44.

23. Matsui S, Fu ML, Katsuda S, Hayase M, Yamaguchi N, Teraoka K, et al. Peptides derived from cardiovascular G-protein-coupled receptors induce morphological cardiomyopathic changes in immunized rabbits. J Mol Cell Cardiol. 1997;29:641-55.
24. López Bergami P, Scaglione J, Levin MJ. Antibodies against the carboxyl-terminal end of the Trypanosoma cruzi ribosomal P proteins are pathogenic. FASEB J. 2001;15:2602-12.

25. Brenière SF, Bosseno MF, Noireau F, Yacsik N, Liegeard P, Aznar C, et al. Integrate study of a Bolivian population infected by Trypanosoma cruzi, the agent of Chagas disease. Mem Inst Oswaldo Cruz. 2002;97:289-95.

26. Talvani A, Rocha MO, Ribeiro AL, Borda E, Sterin-Borda L, Teixeira MM. Levels of anti-M2 and anti-beta1 autoantibodies do not correlate with the degree of heart dysfunction in Chagas' heart disease. Microbes Infect. 2006;8:2459-64.

27. Cunha-Neto E, Coelho V, Guilherme L, Fiorelli A, Stolf N, Kalil J. Autoimmunity in Chagas' disease. Identification of cardiac myosin-B13 Trypanosoma cruzi protein crossreactive T cell clones in heart lesions of a chronic Chagas' cardiomyopathy patient. J Clin Invest. 1996;98:1709-12.

28. Abel LC, Kalil J, Cunha Neto E. Molecular mimicry between cardiac myosin and Trypanosoma cruzi antigen B13: identification of a B13-driven human $\mathrm{T}$ cell clone that recognizes cardiac myosin. Braz J Med Biol Res. 1997;30:1305-8.

29. Yoshikawa T, Baba A, Nagatomo Y. Autoimmune mechanisms underlying dilated cardiomyopathy. Circ J. 2009;73:602-7.

30. Baba A, Yoshikawa T, Ogawa S. Autoantibodies produced against sarcolemmal Na-K-ATPase: Possible upstream targets of arrhythmias and sudden death in patients with dilated cardiomyopathy. J Am Coll Cardiol. 2002;40:1153-9.

31. Iizumi K, Mikami Y, Hashimoto M, Nara T, Hara Y, Aoki T. Molecular cloning and characterization of ouabain-insensitive $\mathrm{Na}(+)$-ATPase in the parasitic protist Trypanosoma cruzi. Biochim Biophys Acta. 2006;1758:738-46.

32. Marcipar IS, Lagier CM. Advances in serological diagnosis of Chagas' disease by using recombinant proteins. In: Rodriguez-Morales A, editor. Current topics in tropical medicine. Rijeka, Croatia: InTech; 2012. Available at: http://www. intechopen.com/books/current-topics-in-tropicalmedicine/advances-inserological-diagnosis-of-chagas-disease-by-using-recombinant-proteins

33. Storino R, Schapachnik E, Barousee J, Leguizamón Palumbo J, Manigot D, De Rosa M, et al. Clasificación clínica de la miocardiopatía chagásica crónica e historia natural. Bol Acad Nac Med B Aires. 1985;63:160.

34. Acquatella H. Echocardiography in Chagas heart disease. Circulation. 2007;115 1124-31

35. McMurray JJ, Adamopoulos S, Anker SD, Auricchio A, Böhm M, Dickstein K, et al. ESC Guidelines for the diagnosis and treatment of acute and chronic heart failure 2012: The Task Force for the Diagnosis and Treatment of Acute and Chronic Heart Failure 2012 of the European Society of Cardiology. Developed in collaboration with the Heart Failure Association (HFA) of the ESC. Eur Heart J. 2012;33:1787-847

36. Camussone C, Gonzalez V, Belluzo MS, Pujato N, Ribone ME, Lagier CM, et al. Comparison of recombinant Trypanosoma cruzi peptide mixtures versus multiepitope chimeric proteins as sensitizing antigens for immunodiagnosis. Clin Vaccine Immunol. 2009;16:899-905.

37. Tijssen P. Processing of data and reporting of results of enzymeimmunoassays. En: Practice and theory of enzimeimmunoassays. Laboratory techniques in biochemistry and molecular biology. Ámsterdam: Elsevier; 1985 $385-421$

38. Wright PF, Nilsson E, Van Rooij EM, Lelenta M, Jeggo MH. Standardisation and validation of enzyme-linked immunosorbent assay techniques for the detection of antibody in infectious disease diagnosis. Rev Sci Tech. 1993;12:435-50.

39. Rassi Jr A, Rassi A, Little WC, Xavier SS, Rassi SG, Rassi AG, et al. Development and validation of a risk score for predicting death in Chagas' heart disease. N Engl J Med. 2006;355:799-808.

40. Barbosa MM, Nunes MCP. Estratificación del riesgo en la enfermedad de Chagas. Rev Esp Cardiol. 2012;65 Suppl 2:17-21.

41. Axelsen KB, Palmgren MG. Evolution of substrate specificities in the P-type ATPase superfamily. J Mol Evol. 1998;46:84-101.

42. Borda ES, Sterin-Borda L. Antiadrenergic and muscarinic receptor antibodies in Chagas cardiomyopathy. Int J Cardiol. 1996;54:149-56.

43. Cunha-Neto E, Duranti M, Gruber A, Zingales B, De Messias I, Stolf N, et al, Autoimmunity in Chagas disease cardiopathy: biological relevance of a cardiac myosinspecific epitope crossreactive to an immunodominant Trypanosoma cruzi antigen. Proc Natl Acad Sci USA. 1995;92:3541-5

44. Masuda MO, Levin M, De Oliveira SF, Dos Santos Costa PC, Bergami PL, Dos Santos Almeida NA, et al. Functionally active cardiac antibodies in chronic Chagas' disease are specifically blocked by Trypanosoma cruzi antigens. FASEB J. 1998:12:1551-8.

45. Umezawa ES, Bastos SF, Camargo ME, Yamauchi LM, Santos MR, Gonzalez A, et al. Evaluation of recombinant antigens for serodiagnosis of Chagas' disease in South and Central America. J Clin Microbiol. 1999;37:1554-60. 